\title{
THE LEARNING EXPERIENCE OF GREATER CHINESE STUDENTS IN FRENCH UNIVERSITIES: A CROSS-CULTURAL PERSPECTIVE
}

\author{
Hsin-I Lee, Kemo Badiane, and Yiru Xu \\ Nanfang College of Sun Yat-Sun University, Guangzhou, China \\ e-mail: Hsini.Lee79@gmail.com
}

\begin{abstract}
Today, more and more Greater Chinese students are motivated to study in Western universities more specifically French universities. This makes France one of the fourth most popular destinations for international students. Using pragmatics and socialcultural constructivist perspectives, this article is aimed at improving the adaptation of the Greater Chinese students benefiting from a French-Greater Chinese university exchange. The method employed in this study was descriptive qualitative research based on interviews and on-line surveys with Greater Chinese students for two academic years before they went to France and while staying there. Special focus was given on what seems to be the most important to Chinese students, leading to adaptation to French university pedagogical methods. Presentation will be given on main characteristics and obstacles faced and the appropriate advice for the elaboration of the syllabus. To summarize, the paper proposes reflections in the sense of designing FFL preparatory syllabi specific to study programs. By listing the real encountered problems and suggesting means to overcome them, the present study can be helpful to FFL teachers and students involved. Implications for teachers, researchers, and learners are highlighted.
\end{abstract}

Keywords: FFL, academic competence, university pedagogical method, FSP (French for Specific Purposes)

\section{PENGALAMAN BELAJAR MAHASISWA CINA DI UNIVERSITAS PERANCIS: PERSPEKTIF LINTAS BUDAYA}

\begin{abstract}
Abstrak
Akhir-akhir ini, makin banyak mahasiswa China tertarik untuk belajar di universitas Barat, terutama Perancis. Hal ini membuat Perancis menjadi satu dari negara pilihan keempat bagi mahasiswa internasional. Dengan menggunakan pragmatiks dan perspektif konstruktivitis sosio-kultural, artikel ini bertujuan untuk meningkatkan tingkat adaptasi mahasiswa China yang berpartisipasi dalam program pertukaran mahasiswa. Penelitian menggunakan metode deskriptif kualitatif dengan intervieu dan survei daring pada mahasiswa China di Perancis selama dua tahun akademik, sebelum dan selama mereka tinggal di sana. Fokus diarahkan pada apa yang dianggap sebagai paling penting bagi mahasiswa China, dengan mengarah pada adaptasi ke metode pedagogik universitas Perancis. Pembahasan akan disampaikan kepada sifat dan kendala utama and saran
\end{abstract}


yang tepat untuk elaborasi silabus. Sebagai ringkasan, artikel akan memberikan refleksi dalam hubungannya dengan perancangan persiapan silabus Bahasa Perancis untuk Penutur Asing untuk program studi tertentu. Dengan menyebutkan masalah yang benarbenar dihadapi dan memberikan saran-saran pemecahan, penelitian ini akan berguna bagi dosen dan mahasiswa bahasa Perancis untuk Penutur Asing. Di bagian akhir, diberikan implikasi untuk dosen, mahasiswa, dan peneliti.

Kata Kunci: Bahasa Perancis untuk Penutur Asing (BPPA), kompetensi akademik, metode pedagogik universitas, Bahasa Perancis untuk Tujuan Khusus (BPTK)

\section{INTRODUCTION}

The Ministry of Education of the People's Republic of China (2017) publishes that the number of Chinese students studying abroad is 608,400 and China is the largest country which outputs international students. According to the recent statistics published by Campus France 2018, France is the first non-English speaking country, with 342,400 international students for the academic year 2017-2018. Following this trend, we found that these Greater Chinese students face many challenges mainly in French university pedagogical methods, competences, academic writings and lectures to name a few. Thus we decided to start a series of research to better understand these phenomena. This research started in 2013 and ended in 2018; it used qualitative research applying online survey. We use online questionnaire in order to reach a large number of participants. Like all the allophone students, the Greater Chinese ones come from different teaching systems, which are really very far from the French system as it is exactly the case of our focus. To be authorized to register in the first cycle of French universities, in the framework of a normal procedure of prior admission, foreign students are usually required to have at least their "DELF B2". However, our Greater Chinese students who benefit from university exchange programs are exempted from these regulations. Whatever the situation, several students might need a prior preparation and/or an integration support so as to better apprehend the complexity of what is awaiting them in France or when they make "a transition to studying in a foreign country" (Lillyman \& Bennett, 2014; Giret, Van de Velde, \& Verley, 2016) : university culture, students' interpersonal skills and higher education method. This very last point is also the stage requiring much time and the most difficult one to understand. That's why the issue is given so much attention. Considering our work's constraints, we won't deal with the different subjects as such in our study, because it only deals with methodology from its crossdisciplinary angle, which is common to all the subjects. The present article is about the teaching of French as a Foreign Language for Specific Purposes - 'FOS' in French, ESP in English.

French for Specific Purposes (FOS) is based on English ESP (English for Specific Purposes) appearing in the 
1980's. It succeeds the functional French and emphasizes on the objectives to be achieved, but little on the means to achieve them (Lehmann, 1993:41; Migdalia \& Rosales, 2016). The FOS is based on the analysis of the needs of language learners (Lee \& Bong, 2019) and pragmatics (speech-acts) and social constructivism theories. According to the social constructivism theory, meaningful learning takes place when individuals are engaged in social activities including interaction and collaboration (McMahon 1997). It is essentially concerned with the notional-functional and communicative approaches. The FOS public is often professional or academic and interested in learning French to achieve professional or academic goals. Mangiante and Parpette (2011) state that the FOS covers all situations, while Damette (2007:7) argues that the FOS is undoubtedly more attractive because it is more focused on the "client", however it covers only part of the public in teaching FOS.

\section{METHOD}

This research study began with the Taiwanese students preparing to study in French universities for the Fall 2013 Semester in France. We conducted a survey between May and August 2013. These students were re-interviewed during their stay in France between November 2013 and January 2014. They were again interviewed the following year targeting a specific sample from May 2014 to January 2015.

This is a survey of voluntary participation via online questionnaires by Campus France in Taipei and Taiwan's university international relations department. The length of stay of the students in France is one academic year or one academic semester. The survey period extends from two to three months before departing from Taiwan (first data collection) until the first trimester of stay in France.

The results of previous surveys of the Taiwanese students helped us conduct a semi-structured interview for Chinese students to better understand the major difficulties they encounter while studying in France. These students were surveyed between November 2017 and January 2018. The students were invited to participate voluntarily in the study and mainly concerned Mainland Chinese students. In accordance with the research methodology for the Taiwanese students, we decided to follow similar methods, that is to say, to interview returning students who spent less than a year in France and those of the first cycle and second cycle.

\section{RESULTS AND DISCUSSION Results}

Our findings were analysed using two main featuress, such as features of the Taiwanese population sample and features of the Chinese population sample.

First, features of the Taiwanese population sample. Heterogeneous population from subjects angle (management and marketing, languages, technology and computer sciences, economics, arts, and others): According to the distribution of subjects in our sample, the ratio of students reading social sciences or exact sciences corresponds to numbers given by a study conducted by MESR- 
DGESIP/DGRI-SIES and MEN-MESR DEPP and published by Campus France in 2014. As for the academic cycles, three-quarters of the surveyed population (68 out of 90 in two years) are first cycle students and a quarter (22 out of 90 in two years) made up of second cycle students.

First, little or inadequate prior French studies: almost two-thirds of students $(58 / 90)$ aren't either up to DELF A2 standard in French or are just up to it; a few more than one-third (32/90) are up to $\mathrm{B} 1$ and $\mathrm{C} 2$ standard in French according to their own projections before their departure to France. Second, Little or not enough information about the necessity of better preparing the stay in the framework of inter-university exchange programs be their information related to their academic needs or information on their daily needs. Third, Ignorance of methods specific to the French higher education: teaching and learning styles, ways of assessing, university regulations, etc. Fourth, Little or not enough information about the institutional organization of French higher education. Fifth, Little or not enough information about French cultural codes and inter-personal skills

Second, features of the Chinese population sample. Heterogeneous population from subjects angle (economics, management, political science, arts, languages, social sciences, creative industry design, technology, and others). According to the distribution of subjects in our sample, the majority of the students were studying management, arts, and social sciences.

As for the academic cycles, three- fifths of the surveyed population (35 out of 52 in two years) are first cycle students and two-fifths (16 out of 52) made up of second cycle students.

Prior French studies: almost onethird of students $(16 / 52)$ are up to DELF A2 and B1 standard in French or are just up to it; half of them $(26 / 52)$ are up to B2; one-fifth (10/52) are up to C1 and C2 standard in French according to their own projections before their departure to France.

This summary of analyses results has helped us better understand challenges we had to overcome. The Greater Chinese students are not the only ones to face the abovementioned problems. Some studies conducted by the French themselves have already mentioned the problems related to foreign students' registration conditions, receptions and knowledge acquisition in French universities (Coulon and Paivandi, 2003; Szymankiewicz, 2005; De Carlo \& Diamanti, 2013; Cuq, 2014; Agulhon \& Ennafaa, 2016; Courtaud, 2018). To better understand the needs of students from the target population, we have gathered them according to the three types of competences which are already mentioned (linguistic, cultural, and academic). In this article, we particularly focus on what seems the most important to us, that's to say Greater Chinese students' needs in terms of French university competences.

\section{Discussion}

The surveys were conducted through internet using bilingual, French and Chinese questionnaires, yet this way didn't enable students to sufficiently 
explain in detail their needs in terms of academic competences. We referred to a field research conducted by Bou (2007) on 111 teachers and researchers of the website of Grenoble University for a complete evaluation of the situation. In the light of their answers, we also better understood that the needs of the surveyed populations were not explained enough in details.

As far as French university pedagogical methods, the principle of the French university work first lies on the comprehension of lessons (lectures, tutorial classes, practical work and seminars). From their understanding of lectures, students jot down notes in order to revise them once at home and master knowledge received from teachers, all this in the purpose of sitting for the different tests, which can be done either in a written or oral form. During the exchange programs, the majority of students are confronted to the specificity of French university pedagogical methods, which can be classified in three categories : lectures, academic writings, and academic speaking tasks. We describe below the characteristics of each of them; we also list the essential tasks a student is expected to perform in French universities so as to be successful in these types of activities, at last we give some guidance advice accompanied with materials that might be useful.

Lectures (or CM in short in French) play an important role in the French higher education. Their objectives are generally knowledge transmission. During the first year of higher education, they aim at facilitating students' initiation in many domains (Bouchard \& Parpette,
2007). They have several characteristics, the most important of which is the teacher speaks most of the time, thus limiting the interaction or even making it inexistent. The student mainly depends on what the teacher wants to deliver him in terms of information and knowledge. However, depending on subjects and teachers, some supporting media (such as slide shows, duplicated lecture notes, videos, etc) are used. Nevertheless, the student should be able to take down notes. In addition to, there are other aspects of lectures requiring from both native and non-native students to make efforts, e.g., classes heaviness and duration. This last aspect was mentioned in the project elaborated by Sperandio in 2004 : foreign students at B1standard in French were tested in laws and economics at Grenoble 2 University; the tests aimed at assessing whether they could follow conferences stretching on time; but these students were remarked to have given up fifteen minutes after. This showed the necessity of combining learning with this type of oral comprehension (lectures, conferences, meetings, etc.,) in the preparatory syllabus before students' arrival in France.

In our point of view, to better prepare students so that they can follow lectures, the following three aspects should beforehand be improved: teachers' speeches, the aspects of bichannel and bisemiotic communication and, lastly note taking. According to their functions, teachers' speeches can be classified into two categories :

The subject speech appropriate to a given subject whose objective is knowledge transmission on a taught 
subject (notional explanation, description, exposé, critical analysis, comparison and reasoning conducted through scientific distance required by this kind of speech).

The pedagogical speech whose purpose is to support students in several ways and forms, including instructions, work advice, explanations, repetitions, reformulations, examples and dictation of important points, and institutional information, etc. This second dimension also includes an important range of discursive processes of explanation that are not far from the distinction made by Eurin and Henao (1992) between an expository speech and an interactive speech. Many registers appear among the several functions of teachers' speeches, meaning a combination of wordings between main and secondary discourses (in the form of synonymies, repetitions, reformulations, etc.). Students should learn how to distinguish these main and secondary discourses.

First, during lectures, knowledge transmission can be done through 'multichannel and multisemiotic communication' (Mangiante \& Parpette, 2011; Bordo, Goes, \& Mangiante, 2016). Only bichannel and bisemiotic communication cases will be considered here. Lectures can be delivered through two speech approaches depending on the subjects or teachers' habits. In this situation, both teachers' speeches and means they use (slide shows, duplicated lecture notes, videos, etc.) on the other hand are combined. People often add comments which are usually redundant, that's to say teachers' oral discourses are about information that are already mentioned by the used materials : teachers' oral texts/explanations and the written texts on the aids are about the same thing, one of them trying to make the other more explicit. This is referred to as bichannel communications during which students receive information in both written and oral forms, therefore requiring from them visual and auditory comprehension. On the other hand, when talking about bisemiotic combination, we refer to the type of communication which is done via two systems of different signs. The former is that of iconic signs (graph, image, diagram, etc.) without any explanatory text, and then comes the second linguistic sign that is the teacher's oral discourse commenting iconic signs and explaining how to read them. The two systems are complementary. Here also, students are required to get auditory and visual receptive skills as in bichannel communications, though the visual reception of an iconic sign is not exactly the same as that of a written text.

Second, the debate on note taking is recurrent in allophone students' concern, likewise for those who use Chinese characters. It's mainly one of the academic skills with a high proportion of requirement because the student is required to perform several tasks at the same time: oral and written comprehension (in case materials are distributed or projected) and note taking techniques. It also depends on a more or less perfect mastery of the type of speeches delivered by the teacher, and particularly in its double aspect bichannel and bisemiotic we have just talked about. This is, at last, linked to the cultural dimension : students are not accustomed to note taking during 
the learning process in their native countries.

All these factors don't facilitate note taking for students. We suggest the teacher/designer to take into account students' level in French while acting. No matter what, students must be encouraged to go to the teacher right from the beginning of lectures so as to get these projected or distributed materials in class. If ever students can meet teachers and get these materials, it will help them prepare classes beforehand and better understand lectures they attend. Students can also ask for these materials after their classes : in this case, teachers free allophone students from the difficult work consisting of juggling with oral comprehension and/or written comprehension in reception on the one hand, and writing for taking notes on the other hand. The latter seems particularly laborious at the beginning of an exchange program sojourn.

In front of all these problems, many approaches should be taken into account to facilitate the understanding of lectures : people should work on an adequate type of communication specific to lectures in their cross-disciplinary aspect, while taking into account awareness-raising on cultural and discursive phenomena. To help learners get accustomed to oral understanding of lectures, teachers/ designers can select some materials for less specialized contents, for example lectures meant to a large audience that are available in Internet via 'canal U', 'iTunes U', 'France Université Numérique - FUN', etc., (see Volume II of Chapter 10 appendixes from Lee's Ph.D dissertation, Lyon 2016). The great majority of lectures main characteristics are found in this type of resources (their complexity and length, subject-related speeches and pedagogical ones; bichannel and bisemiotic communications, etc.). Firstly, these characteristics should be worked on by isolating them. Secondly, in the purpose of widening the range of possible cognitive treatments, we will have to guarantee the diversity of proposed activities on the same aspect of lectures. We should not forget to treat the least significant elements, yet useful for general understanding of lectures, such as tasks instructions (they are generally given at the beginning of lectures); reviewing/announcement/reformulation techniques (indicating important notions or elements); linguistic routines forming lectures sequences and the different language registers, etc.

We suggest the teacher/designer to select first the types of topics s/he wants to deal with via websites proposing several lectures on different subjects. Then, s/he consults the work entitled 'French for Academic Purposes' : where its authors propose relevant models of (pedagogical) lesson plans dealing with the major academic aspects. Moreover, on the website of their publishing house GUP (Grenoble University Press), the authors give complementary materials and about forty targeted lesson plans that are downloadable.

As far as note taking is concerned, we propose to work in two stages. The former is devoted to students from all levels and the latter is more for students who have already acquired at least B1 level and are attending the exchange program in French. The first stage is that of sensitization, and cultural reflection on 
note taking practice. Then, its principal features will be presented to find the moments when the teacher gives strong and repeated clues (either in a written or oral form) facilitating note taking. When the clues are orally given, they are generally characterized by a kind of voice lifting, and slowness in sentence delivery, a more insisting tone, etc. unlike the conversational style and its rather quick and less articulate delivery.

At the second stage, students have been first initiated into some technical aspects of note taking, such as quick codification, abbreviations, symbols, etc. Then, exercises were conducted on the treatment of teachers' speeches (the essential stage is the selection of information to keep) from the analysis of lectures extracts. We strongly advise to reuse exercises which were used during the analysis of the teacher's speech and some aspects of bichannel and bisemiotic communication. Teachers are suggested to propose activities for each of the two types of communication, so as to help students better understand what they should jot down. For this stage we also advise the consultation of lesson plans (see Volume II of Chapter 10 appendixes from LEE Hsin-I's Ph.D dissertation, Lyon 2016).

On the other hand, if students face more problems in note taking, it's simply because they are not so good at French or teachers' materials are not available, therefore they have to resort to the notes of other students who are native speakers. In this case, the teacher/designer should imagine additional activities to empower them to read students' handwritings. It is generally very difficult for the Greater
Chinese students to decipher Europeans' cursive script because their mother tongue is not alphabetical; they have not learnt to read written words without separating letters. This exercise will give students an additional asset for they need deciphering teachers' handwriting on the board.

Concerning academic writing, the difficulties are essentially linguistics, but they are also linked to the capacity of understanding lectures, note taking and note reconstruction done through their reformulation to meet the requirements of different academic writings fixed by each subject in accordance with academic work, which generally facilitates the assessment of students' work. These academic tasks also depend on both the academic methodological specificity and the subject involved. As Cavalla, C. (2007:28-29) shows, there are many aspects of academic writings: 'dealing with academic writing in itself is not new', still according to her, no matter what they are, 'students - foreigners or not - need many types of knowledge: scientific (subject-based knowledge), methodological and linguistics (lexicon, structures contributing to make sense, etc.).

Here, we don't talk about the types of knowledge students should acquire, but rather how to work on writing codification and requirements so that students can meet these methodological rules. We will first identify the different academic writing genres referring to the works by Bou and Cavalla (2011) and by Mangiante and Parpette (2011). Then, we will try and identify cross aspects of these different types of writings valid for all the subjects, with the idea of identifying skills that are fundamentally important 
for academic writing. Last, we will suggest strategies about some key elements so that students can be skilled in academic writing.

In the classification of the different writing genres, Mangiante and Parpette (ibdm) focus on various discipline expectations in terms of writing at BA and MA levels, be it experimental sciences or social sciences courses, taking into account the importance of cross aspects which might interest different university subjects. However, these expectations take different forms to be adapted to each subject's needs and particularly to the specialized lexicon.

Authors explain that these three categories of writing are not separated from one another but are complementary and progressive in the French university cycle. Course reconstructions are mainly done in the first and second years of the first cycle respectively known as 'L1 and L2' but even in the third year (BA level); comments and summaries are done from the second year and particularly focused on at BA and MA levels; as for case studies and simulations, they are more professional world-oriented, therefore they are more worked on at Master level but they first appear at BA level in some courses, such as in law and economics.

For the typology of academic writings we are also interested in the works by Bou and Cavalla (2011), referring to a field research conducted by Bou in 2007 in Grenoble universities. The work focuses on the situations of specific writings from the Master level. However, the three categories of writings we mentioned above (see above, Table 1) about the first and second academic

Table 1 Typology of academic writings according to Mangiante and Parpette

\begin{tabular}{|c|c|}
\hline Domains & Academic writing situations \\
\hline Courses/ & - Write the definition of terms or specific notions. \\
\hline lectures & - Answer questions from the course (who, what, why, how). \\
\hline Reconstruction & $\begin{array}{l}\text { - Reproduce a scientific demonstration (mathematic/experimental) with } \\
\text { different data. }\end{array}$ \\
\hline \multirow[t]{3}{*}{$\begin{array}{l}\text { Comments and } \\
\text { summaries }\end{array}$} & $\begin{array}{l}\text { - Answer questions related to the course from documents (articles, diagrams, } \\
\text { charts) or data and parameters resulting from experimentation (for example } \\
\text { the case of tutorial classes) }\end{array}$ \\
\hline & $\begin{array}{l}\text { - React to described situations, express one's idea, a reflection, a comment and } \\
\text { compare }\end{array}$ \\
\hline & $\begin{array}{l}\text { - Write a summary from many documents on a single topic : gather and put in } \\
\text { perspective several viewpoints, speeches delivered in different situations/ } \\
\text { forms, classify and compare, contrast. }\end{array}$ \\
\hline $\begin{array}{l}\text { Case study and } \\
\text { simulation }\end{array}$ & $\begin{array}{l}\text { - Analyze a situation from specific parameters (predictable and deviant), } \\
\text { interpret data and adapt them to a diagram previously seen during the course, } \\
\text { complete and give argument. }\end{array}$ \\
\hline & - Reuse and exemplify. \\
\hline & $\begin{array}{l}\text { professional type) and proceed to an adapted professional writing, condense, } \\
\text { summarize and order the necessary information for the accomplishment of a } \\
\text { specialized task emanating from professional life. }\end{array}$ \\
\hline
\end{tabular}


cycles might always be carried out at Master level but only with a different requirement density. The interest of this summary table is analyzing specific writing situations from two angles, that is to say reception and production. Thanks to the distinction of domains (here, we only recapitulate domains which are about the surveyed population during the research we conducted) the teacher/ designer can work more on certain types of writing depending on the target audience.

Thanks to the table we can notice what should be given priority to for the written tasks required by the university in subjects students select depending on the occurrence of these tasks within different subjects. As for the reception of specific writings, the results of our research gather many points already dealt with by Bou and Cavalla. About production, here case study, summaries and reading notes will have priority. Probably, if we prior knew the subjects students want to read, we could just prepare them to these subjects specific written work; but if you want to address students reading various subjects, it is advisable to deal only with the most fundamental points valid for all the subjects in a cross perspective. It is opportune to better prioritize these fundamental points, if we want to be efficient, despite little time generally devoted to this type of training. And yet, the first of these fundamental points,

Table 2. Summary of academic written tasks according to Bou and Cavalla

\begin{tabular}{|c|c|c|}
\hline \multirow[t]{2}{*}{ Domains } & \multicolumn{2}{|c|}{ Specific writing situations } \\
\hline & In reception & In production \\
\hline $\begin{array}{l}\text { Mathematics and } \\
\text { computer science }\end{array}$ & $\begin{array}{l}\text { Technical documents ; diagrams/ } \\
\text { plans }\end{array}$ & Case study; Summaries; CV \\
\hline Physics-Chemistry & Technical documents; Chipboard & $\mathrm{CV}$ \\
\hline Engineering sciences & $\begin{array}{l}\text { Technical documents ; Data bases ; } \\
\text { Diagrams/plans; Procedures; Legal } \\
\text { documents }\end{array}$ & Summaries \\
\hline Medecine & $\begin{array}{l}\text { Technical documents ; Diagrams/ } \\
\text { plans; Procedures; Data bases }\end{array}$ & Case study; Summaries \\
\hline $\begin{array}{l}\text { Economics, } \\
\text { Management } \\
\text { Finances }\end{array}$ & $\begin{array}{l}\text { Press articles ; Data bases; Legal } \\
\text { documents; Manuscript documents }\end{array}$ & $\begin{array}{l}\text { Case study; Summaries; Reading } \\
\text { notes; Essays; CV ; Comments }\end{array}$ \\
\hline Literature & Data bases & $\begin{array}{l}\text { Reading notes; Summaries; } \\
\text { Informative summaries; } \\
\text { Electronic writings }\end{array}$ \\
\hline Social sciences & $\begin{array}{l}\text { Data bases ; Manuscript documents; } \\
\text { Diagrams/plans; Philosophical } \\
\text { essays }\end{array}$ & $\begin{array}{l}\text { Reading notes; Summaries; } \\
\text { Case study; Essays; } \\
\text { Comments; Questionnaires; }\end{array}$ \\
\hline Language sciences & $\begin{array}{l}\text { Technical documents; Data bases; } \\
\text { diagrams/plans; Press articles }\end{array}$ & $\begin{array}{l}\text { Summaries;Reading notes; Case } \\
\text { study; Electronic writing; } \\
\text { Questionnaires }\end{array}$ \\
\hline
\end{tabular}

The Learning Experience of Greater Chinese Students in French Universities: A Cross ... 
essential for the success of the abovementioned three performances, is the mastery of the French discursive logic. This is all the more true than many academic works are based on an argumentative logic particularly developed in France. In FFL graduations (Delf/ Dalf), this argumentative logic begins at B2 level. That is why B2 level is required to pursue higher education in French.

To initiate students to this discursive logic as required by French universities, one of the methods which can be used and really advised is that one indicated by Mangiante and Parpette (2011:167). It is about resorting to authentic documents as good and well-structured written texts (correct versions or annals), giving them to students and studying all the discursive mechanisms. Showing in a very practical way that a given paragraph is structured, what its logical structuring are, how, for instance, the first sentence of the paragraph announces its content, how the last one well concludes the paragraph and how the idea is perfectly developed between the two sentences. This helps show how the French elaborate writing, which construction is not the same in all the countries. Students should be shown models through documents about the various types of written works which they will have to work on in reception or in production according to Raymond and Véronique (1997), Kleemann-Rochas, Farina, Fernandez and Michel (2003).

These activities for the location of pragmatic, enunciative, textual and linguistic clues will allow students to be trained to write passages of academic written works. Each point will necessitate a link referring to didactic sequences of reading and writing adapted to the chosen topic because attending simply a theoretical lecture is not enough; after showing via materials the discursive process of French logic, the most important step is getting students implement them in personal and individual productions. Students' personal productions will be used as pedagogical tools for the next step. It will consist in analyzing these written productions by students themselves. It will be good to select the best productions and have all the group study them to find and identify their structures, characteristics and logic coherence. This is not for making students, who might have done mistakes, feel guilty, but it's about showing them what is good (what was well done, well understood and well carried out) and it's also about showing how errors or remaining awkward (expressions) could have been corrected on the other hand because pedagogical aids should be texts written by the French as well as those written by students themselves.

People should benefit from the analysis of texts which are already written to show the differences between the various wording processes: for example, explanatory, injunctive, directive wordings, etc. In the first case, people will analyze all the cause relations, all the words, all the logic structuring which permit to highlight causes and consequences. In these various wording processes which the teacher will consider depending on the different kinds of academic written works which discursive mechanisms are not the same. To help students acquire the necessary skills for 
being successful in academic writings we refer to tools mentioned in the appendixes of Chapter 10 : academic writing in the above quoted Ph.D dissertation paper.

It should not be forgotten that among these various types of writings there is a type of written work which students sit for as a final assessment. They are exam papers or exercises of continuous assessment. There are instructions which trigger off or appeal to academic written work. They direct the needed writing towards a precise textual genre. For this reason, we ask the teacher to use authentic documents to analyze with students all the instructions, the textual genres and implicit methodological data so as to show the characteristics which are the subject of pedagogical exploitation in preparatory classes in the aim of making students more skilled at written tests' time. Let's take an example given by Mangiante and Parpette (extracted from an L2 tutorial class exam paper on economic policies at Artois University). This example illustrates what we want to advise teachers so as to cope with this type of coaching.

Questions :

1) Comment the evolution of employment in France.

2) Why should measures on joblessness be debated?

3) How is the cost of employment policy shared? Comment.

4) What do migrants' activities represent in the economy of France?

5) What are the expected benefits from part time unemployment?

6) Are there efficient policies to cope with employment crisis?

Students are requested here by instructions in the imperative and questions referring to lectures and provided documents, acting as an echo to main notions dealt with, activated by key words (employment evolution, joblessness, employment policy, migrants' activities...) The targeted textual genre here is the summary of documents induced by the word 'comment' supposed to put notions learnt in class and their declension in perspective in documents which are external to delivered lectures with questions. This textual genre is not clarified, it is the result of a methodological implicit' (Mangiante \& Parpette, 2011:125).

Academic oral productions require from students to be able to ask questions, exchange ideas or opinions, give arguments, continue discussions in relation to subjects they read, take the floor in front of a specialized audience, present an exposé, etc. These oral tasks require other tasks before they are carried out. For example, students should first understand lectures, know how to take notes or at least know how to use notes taken by someone else, and get used to the French methodology in connection with academic oral productions.

The necessity of these precise skills leads us to questioning about students' required level in French. In documents published by the CECRL on oral skills, the descriptors tell us that from B1 level the speaker should be able to assess his/ her capacities in the following way: "I can briefly give the reasons and explanations of my opinions or projects" (CECR, 2000:26) and at B2 level his/her capacities should be the following: "I can express myself in a clear and detailed way on a wide range of 
topics related to my personal interests. I can develop a viewpoint on current affairs and explain advantages and drawbacks of different situations." (Ibidem, 2000:27). Thus, one can see the reason why, in the domain of admission procedure, a minimal level of B2 is required to get access to the first cycle of French universities. Students who are the target of the study do not at all go as far as this level; therefore their difficulties are still minimal. It is interesting to list the main communication problems: (a) asking questionsm, (b) communicating with the teacher, and (c) maintaining discussion with working party members.

These difficulties related to oral communication in universities, such as asking questions, exchanging ideas or opinions, giving arguments, conducting discussions in relation with subjects students read, taking the floor, etc., should be first tackled. It's probably during tutorial/practical classes, where the need of interacting is stronger, that our students face these difficulties. We all know that during lectures people are in a situation of monologue, because in general only the teacher takes the floor, and even if he takes into account the presence of his/her audience, and delivers a speech adapted to the audience, this cannot really be regarded as a true and genuine dialogue, whereas during tutorial/practical classes, the diagram is rather different : the teacher expresses himself, so do students. Moreover, there is an active/a dynamic pair interaction in the group, hence a situation of polylogue, since students do their productions in small groups, in which the interaction is very dynamic and active. These problems related to interaction is not specific to our students only : according to a survey conducted by Bou and Cavalla (2007), more than half of the teachers can notice that the allophone students hesitate to take the floor during classes.

As far as specific academic oral performances are concerned, students showed they had problems with 'exposé' only. Undoubtedly, we cannot find where the word 'exposé' is used in the table below filled in by Bou and Cavalla, which is a summary of academic oral tasks. In fact, the Larousse dictionary defines the word 'exposé' as follows: 'Written or oral explanatory development of something; Analysis : giving an account of the situation; Short development on a precise topic'. We suppose that our students regard any type of oral presentation during academic work as an exposé. As newcomers who were integrated in the French academic system only a few months ago, they cannot distinguish the names of all the work they perform. Therefore, it seems people should not give much importance to the word 'exposé' used by our students and instead they (people) had better confine themselves to the classification of oral situations elaborated by Bou and Cavalla, on the basis of their survey on 111 teachers and researchers.

Among all the oral tasks mentioned in the table, we can identify those on which we have mainly insisted on in relation to their frequency among subjects chosen by students. They have to work more on debates, discussions, and demonstrations. All these types of oral speeches require the capacity of expressing oneself, describing, comparing, explaining, giving arguments on a 
Table 3. Summary of academic oral tasks in specific oral situations (Bou \& Cavalla)

\begin{tabular}{ll}
\hline Domains & Specific oral situations \\
\hline $\begin{array}{l}\text { Mathematics and computer } \\
\text { Physics-Chemistry }\end{array}$ & Presentation of technical studies \\
Engineering sciences & $\begin{array}{l}\text { Demonstrations ; Laboratory communication ; Discussions } \\
\text { Presentation of technical studies; Demonstrations ; } \\
\text { Discussions; Debates }\end{array}$ \\
Medecine & $\begin{array}{l}\text { Debates ; Discussions ; Demonstrations ; Laboratory } \\
\text { communication }\end{array}$ \\
Economics, Management, & Debates ; Simulations and role play ; Discussions \\
Finances & Debates \\
Literature & Debates ; Laboratory communication ; Demonstrations ; \\
Social sciences & Experiment reports ; Discussions \\
Language sciences & Video ; Debates ; Laboratory communication; \\
& Demonstrations ; Experiment reports, Discussions \\
\hline
\end{tabular}

topic depending on subjects they read. About these academic oral performances, we suggest teachers to also work on them in order of importance taking into account both their interdisciplinary and cross-disciplinary degree. Furthermore, the oral academic tasks listed by Bou and Cavalla, show that in universities it is important to acquire argumentative skills. They present one of the interdisciplinary skills connecting language level and academic methodology which should be acquired by students.

It is about training students to academic oral productions. We suggest working in three steps.

In the first step, we choose recorded audiovisual conferences, short exposés or classes delivered by French teachers. These audiovisual documents are visualized by students who are also asked to pay attention to three things only. First, they have to discover and observe extra linguistic elements. In an oral exposé exactly done as the French would do, there are obviously the voices, gestures, body attitudes or speech structuring : all these elements are not linguistic elements but are very important in an oral exposé. The second point, students should pay attention to, is about the different materials used to better transmit the message. Lastly, the final point is, this time, in the words of s/he who speaks: they are called metadiscursive elements, which means that regardless of the exposé content, the speaker will intervene about what $\mathrm{s} / \mathrm{he}$ says, stresses the outline or tells that $\mathrm{s} /$ he is about starting. The final goal of all these metadiscursive elements is helping the listener. Here, it is about explaining the structure of the oral exposé : register changes made during the speech, the adopted point of view is explained, an outline is presented, the problem of the exposé topic is highlighted, and it is stated we are drawing to a conclusion. Let's take an example on the final point : while concluding, we can, for instance, say "and I will end by this", 
which means the speaker is concluding. The sentence "I finish by this" has nothing to do with the content of the orator's speech, but it's just a way of showing how far s/he has gone in the exposé. All these metadiscursive points are extremely important. In this first step, students observe an audiovisual document from these three angles.

For the second step, we advise teachers to mainly direct their training on extra linguistic and metadiscursive points. This step is the extension of the preceding one : from elements observed in the first step, the teacher helps students identify and classify the bulk of main metadiscursive processes in an exposé, to which they can resort to clarify and organize their own exposé when the time comes. From exposés which are viewed, it is essential to identify and classify elements which make its structure more visible : giving the topic before starting, presenting the plan, giving the problem of the expose topic, and the different moments that follow on from each other to result in the comprehension of the exposé. It will be advisable to establish at the end of the second part a typical list of these processes structuring any oral production, which will be used as criteria for the appreciation of the work in the third step. Once the learner succeeds in distinguishing this metadiscursive system (a list of forms and linguistic operations specific to oral production), the final step can be tackled, but this can only be taken into account provided that students, after a careful observation and classification of all these metadiscursive elements, have understood their importance and internalized elements themselves.

\section{CONCLUSIONS}

The purpose of this paper is to help the Greater Chinese students benefiting from a French-Greater Chinese university exchange to improve their adaptation. According to the recent statistics by Campus France 2018, France is the first non-English speaking destination for the academic year 2017-2018. Thus, our findings show that these Greater Chinese students encounter many challenges in French university, including academic competences, pedagogical methods, lectures, academic writings, academic oral productions. The methodology used in this research was descriptive qualitative research based on interviews and online surveys with Greater Chinese students for two academic years before going to France and while staying there. To better understand these phenomena under study, we explore pragmatics and social constructivism theories. According to the social-cultural constructivist theory, meaningful learning occurs when individuals are engaged in social activities, such as interaction and collaboration (McMahon, 1997).

The study we conducted is part of one of CECR designers' objectives: people should tackle in FFL classes 'as fully as possible what learners of a language should learn so as to use it in communication.' (2001:9)

We are only suggesting a way of teaching: going from observation, inviting students to identify and analyze main processes of academic techniques; students will be trained for simulation activities which will include presented techniques. Much more training hours should be devoted to these stages, and we 
recommend concerned universities, particularly universities where there is a French department, to integrate this type of classes in their degree course, this will mainly interest many Greater Chinese students in French departments who benefit every year from exchange programs with France or those who decide to continue their studies in France after having completed their studies in Greater China.

Concerning the limitations of our study, the researchers recognize that the samples are not big enough (but the objective of this heuristic research is to identify the basic and transdisciplinary needs of Greater Chinese students in French higher education) and it is preferable to study by academic discipline to better identify the specific needs of each discipline.

The study will be useful not only in academic research but also in understanding how to better prepare Greater Chinese students to improve their learning experiences in French higher education. The advantage of such quantitative data processing is that it makes it possible to compare groups and to check if the differences between them are statistically significant. On the other hand, the fact that groups are not randomly constituted is a bias that makes it difficult to compare them (Van der Maren, 1996). Therefore, we encourage further research should collect data randomly to compare the results and see how this could affect Greater Chinese students' learning experiences in French higher education system.

\section{ACKNOWLEDGEMENTS}

The researchers would like to thank the grant from the Guangdong Province as part of a provincial project entitled « Gāoxiào guójì fùhé xíng fēi tōng yòngyǔ réncái péiyù yánjiū, No. 2017GXJK236».

\section{REFERENCES}

Agulhon, C. \& Ennafaa, R. (2016). Les étudiants étrangers. Des trajectoires spécifiques, in J.F. Giret, C. Van de Velde \& C. Verley (dir.), Les vies étudiantes. Tendances et inégalités. Paris : La Documentation Française. coll. Études \& recherche. pp. 293307.https://hal.archives-ouvertes. fr/hal-01455128/document

Bordo, W., Goes, J. \& Mangiante, J.M. (2016). Le français sur objectif universitaire: entre apports théoriques et pratiques de terrain. Arras : Artois Presses Université. https://livre. fnac.com/a10106402/WidianBordo-Le-francais-sur-objectifuniversitaire-entre-apportstheoriques-et-pratiques-de

Bou, P. \& Cavalla, C. (2011). Un référentiel-outil de compétences méthodologiques, in L. Cadet, J. Goes \& J.M. Mangiante. Langue(s) et integration: Dimensions institutionnelle, socio-professionnelle et universitaire. Suisse : Peter Lang. pp. 365-381. Available at : https://hal.archivesouvertes.fr/hal-00699920/ document

Bouchard, R. \& Parpette, C. (2007). Autoportrait de l'enseignantchercheur en auteur/acteur : Jeu de postures et reformulations dans les cours magistraux de $1^{\mathrm{e}}$ année. LIDIL. 
(35), 119-138. DOI: $10.4000 /$ lidil.2253

Conseil de l'Europe. Division des politiques linguistiques. (2001). Un cadre européen commun de référence pour les langues : apprendre, enseigner, évaluer. Paris : Didier. https://rm. coe.int/16802fc3a8

Coulon, A. \& Paivandi, S. (2003). Les étudiants étrangers en France: l'état des savoirs. Rapport pour l'OVE (Observatoire nationale de la vie étudiante). Paris: Université de Paris 8, centre de recherches sur l'enseignement supérieur. http:// www.ove-national.education.fr/wpcontent/uploads/2019/01/872e rap_tr_ove.pdf_-1.pdf.pdf

Courtaud, L. (2018). Médiations linguistique et culturelle dans le cadre formatif universitaire. De la traduction à l'appropriation. Recherches en didactique des langues et des cultures. Les cahiers de l'Acedle. 153. DOI: $10.4000 /$ rdlc. 3703

Cuq, J.P. (2014). Temps, espace et savoirs en didactique du FLE. Intercâmbio: French Studies Journal. (7), 6-20. https://hal-amu.archives-ouvertes. fr/hal-02119775/document

Damette, E. (2007 :7). Didactique du français juridique: français langue étrangère à visée professionnelle. Editions L'Harmattan. http://www. editions-harmattan.fr/index. asp?navig $=$ catalogue $\&$ sr $=7$

De Carlo, M. \& Diamanti, L. (2013). Les vécus des étudiants Erasmus pendant leur séjour à l'étranger : un apprentissage expérientiel. Ela. Etudes de linguistique appliquee. (1), 29-46.https://www.cairn.info/ revue-ela-2013-1-page-29.htm?try_ download $=1$

Eurin-Balmet, S. \& De Legge, M.H. (1992). Pratiques du français scientifique. Paris : Hachette.

Giret, J.F. Van de Velde, C. \& Verley, É. (2016). Les vies étudiantes. Tendances et inégalités. Paris : La Documentation Française.

Kleemann-Rochas, C., Farina, G., Fernandez, M. \& Michel, M. (2003). Comment rédiger un rapport, un mémoire, un projet de recherche, une activité de recherche en cours. Firenze : Centre de langues de l'Institut universitaire européen. https://www.unioviedo. es/ecrire/redigera.pdf

Lee, H.I. (2016). L'adaptation des étudiants en programme d'échange interuniversitaire franco-taïwanais Pourquoi et comment envisager un programme préparatoire de FLE à leur intention. Doctoral dissertation, Université Lumière Lyon 2, Lyon. h t t p : / / w w w.theses.fr / 2016LYSE2046

Lee, M. \& Bong, M. (2019). Relevance of Goal Theories to Language Learning Research, System, in Press Corrected Proof. https://doi.org/10.1016/j. system.2019.102122

Lillyman, S. \& Bennett, C. (2014). Providing a positive learning experience for international students studying at UK universities: A literature review. Journal of Research in International Education. 13(1), 6375.https://doi.org/10.1177/ 1475240914529859

Campus France. (2018). Attractivité en hausse: Les étudiants étrangers encore plus nombreux qu'en 2016 dans 
l'enseignement supérieur français. https://www.campusfrance.org/fr/ attractivite-en-hausse-les-etudiantsetrangers-encore-plus-nombreux-quen-2016-dans-1-enseignement

Mangiante, J.M. \& Parpette, C. (2004). Le Français sur objectif spécifique : de l'analyse des besoins à l'élaboration d'un cours. Paris : Hachette. https://hal. archives-ouvertes.fr/hal-00376582

Mangiante, J.M. \& Parpette C. (2011). Le français sur objectif universitaire. Grenoble: PUG, 252 p. file:///C:/ Users/acer/Downloads/PUG_ Extrait_Fran_ais_sur_objectif_ universitaire.pdf

McMahon M. (1997). Social Constructivism and the World Wide Web - A Paradigm for Learning. Paper presented at the ASCILITE conference. Perth, Australia. http:// www.ascilite.org/conferences/ perth97/papers / Mcmahon / Mcmahon.html

Migdalia, P. \& Rosales, R. (2016). Language for Specific Purposes, English for Specific Purposes, Volume 43, July 2016, pp. 74-76. Available at : https://doi. org/10.1016/j.esp.2016.04.002

Cavalla, C. (2007). Réflexion pour l'aide à l'écrit universitaire auprès des étudiants étrangers entrant en Master et Doctorat, in J. Goes, J.M.
Mangiante (eds), L'accueil des étudiants étrangers dans les universités francophones. Arras: Artois Presses Université. pp. 37-48.https://hal. archives-ouvertes.fr/hal-00380482/ document

Raymond, R. \& Véronique, D. (1997). Pratiques de lecture de français langue étrangère à l'université, in Taillefer, G. \& Puch, A.K. Lecture à l'université : langues maternelles, secondes et étrangères. Toulouse: Presses de l'université de sciences sociales.

Sperandio, C. (2004). Projet Acolad. Aide à la compréhension longue et à distance. Rapport de stage de DESS. Université Stendhal à Grenoble.

Szymankiewicz, C. (coord.) (2005). Les conditions d'inscription et d'accueil des étudiants étrangers dans les universités. Rapport à Monsieur le Ministre de l'Education Nationale, de l'Enseignement Supérieur et à la Recherche. 2005-053. https://www.animafac.net/media/ fichiers / PDF/Etudiants $\mathrm{i} n \mathrm{t}$ e $\mathrm{r} \mathrm{n}$ a $\mathrm{t}$ i o $\mathrm{na} \mathrm{ux/}$ nrconditionsdinscriptionetdaccueil.pdf

Van der Maren, J. M. (1996). Méthodes de recherche pour l'éducation (2eme édition). Bruxelles: De Boeck. (1ere éd. 1995). http://hdl.handle.net/ $1866 / 4688$ 